\title{
Perancangan Sistem Informasi Manajemen Rumah Sakit Modul Akuntansi Dan Keuangan
}

\author{
Tantony Hardiwinata $^{1}$, Putu Wira Buana ${ }^{2}$, Ni Kadek Ayu Wirdiani ${ }^{3}$ \\ Jurusan Teknologi Informasi, Fakultas Teknik, Universitas Udayana \\ Jalan Kampus Bukit Jimbaran, Bali, Indonesia \\ 1nicolastantoni@yahoo.com \\ 2wbuana@it.unud.ac.id \\ 3ayu_wirdi@yahoo.com
}

\begin{abstract}
Abstrak
Sistem Informasi Manajemen Modul Akuntansi dan Keuangan dalam suatu rumah sakit sudah wajib ada, karena transaksi yang terjadi dalam suatu rumah sakit sudah begitu banyak. Transaksi yang tidak dicatat dengan baik, sangat sedikit kesempatan dalam pembuatan pertimbangan dan keputusan yang baik. Modul Akuntansi dan Keuangan dalam meningkatkan manfaatnya, data harus dicatat secara sistematis, diringkas dan dikelompokkan, serta disajikan dalam laporan. Pencatatan transaksi secara manual masih menjadi kendala untuk mendapatkan hasil pencatatan yang baik karena kesalahan-kesalahan dalam pencatatan transaksi sering terjadi serta waktu yang diperlukan untuk mendapatkan suatu laporan keuangan cukup lama. Pada penelitian ini akan dibuat sebuah Sistem Informasi Manajemen Akuntansi dan Keuangan yang berguna untuk mengatasi kendala-kendala pada proses akuntansi yang dilakukan secara manual. Sistem manajemen ini mencakup pencatatan dalam penjurnalan, buku besar, dan pembuatan laporan. Sistem informasi manajemen ini berupa Diagram Konteks, Diagram Berjenjang, Overview Diagram, Diagram Alir Data, Database, dan GUI (Graphical User Interface).
\end{abstract}

Kata kunci: Rancangan, Sistem Informasi Rumah Sakit, Modul Akuntansi, Diagram Alir Data.

\begin{abstract}
Module Management Information System of Accounting and Finance in a hospital is required, because the transactions that occur in a company already so much. Transactions that are not recorded properly, there's no chance in making judgments and decisions well. Module of Accounting and Finance to increase its benefits, the data must be systematically recorded, summarized and grouped, and presented in the report. Manually recording transactions is still a constraint to get a good recording results because of errors in recording transactions often occur as well as the time required to obtain a sufficiently long financial statements. In this study will be made of a system of management accounting and financial information that is useful to overcome obstacles in the accounting process is done manually. The management system includes recording in journalizing, ledgers, and report generation. The management information system in the form of context diagram, diagram Tiered, Overview Diagram, Data Flow Diagrams, Database, and GUI.
\end{abstract}

Keywords: Design, Hospital Information System, Accounting Module, Data Flow Diagram.

\section{Pendahuluan}

Perkembangan teknologi yang terjadi pada saat ini sudah semakin pesat, begitu juga dengan kebutuhan akan informasi yang cepat. Rumah sakit merupakan sebuah lembaga yang berguna untuk menangani pelayanan kesehatan pelayanan kesehatan individu, seperti rawat inap, fasilitas rawat jalan, dan perawatan darurat [1]. 
Sistem Informasi Manajemen Rumah Sakit (SIMRS) menerapkan pola tarif rumah sakit yang dapat disesuaikan berdasarkan pada pedoman nasional, yaitu dengan mengisi data master dibagian keuangan, dan rancangan mempermudah bagi petugas khususnya di bagian Modul Akuntansi dan Keuangan dalam menjalankan tugasnya sehari-hari, dikarenakan masih banyak rumah sakit di Indonesia menggunakan sistem manual di bagian Modul Akuntansi dan Keuangan.

Sistem Modul Akuntansi dan Keuangan yang mencatat semua aspek keuangan yang timbul dari kegiatan-kegiatan yang terjadi pada Medical Information System, pencatatan hutang piutang, invoice, pelunasan, inventory control (obat, bahan-bahan medis, dan barang-barang di bagian Modul Sarana Prasarana), point-of-sales, sampai laporan-laporan seperti neraca, laba rugi, buku besar, dan sebagainya baik untuk pasien rawat jalan, inap, maupun gawat darurat [2].

Tujuan Perancangan Sistem Informasi Manajemen Modul Akuntansi dan Keuangan adalah yakni mempermudah, mempercepat, meringankan beban kerja pelayanan, dan menghemat kertas dalam pencetakan laporan akhir periode.

Yudhistira Adi Nugraha Paturusi membuat sebuah perancangan Sistem Informasi Rekam Medis yang Terintegrasi Antar Rumah Sakit berbasis Social Network Web [3]. Perancangan dilakukan dengan merancang Database dan Graphical User Interface. Rika merancang sebuah Sistem Informasi Laboratorium Rumah Sakit Kanker Dharmais. Perancangan dilakukan dengan menggunakan metode TAS (Total Architecture Syntesis). Perancangan Metode TAS dilakukan dengan lima tahap pelaksanaan. Perancangan dilakukan dengan merancang Database dan GUI (Graphical User Interface) [4].

Nur Rohman membangun sebuah Website Informasi Pelayanan Rumah Sakit Cakra Husada Klaten. Perancangan dilakukan dengan merancang ERD (Entity Relationship Diagram), Diagram Konteks, DFD (Data Flow Diagram), dan PDM (Physical Data Model) [5]. Irfan Dwi Jaya membuat sebuah Aplikasi Administrasi Rumah Sakit Dr. AK. Gani Palembang. Perancangan dilakukan dengan merancang Diagram Konteks, Diagram Dekompisisi, DFD, ERD, PDM, dan GUI [6].

Eky Bangun Mukti membuat Perancangan Sistem Informasi Pelayanan Rawat Jalan Berbasis Desktop pada Puskesmas Brati Kab. Grobogan. Rancangan dibuat dalam bentuk Activity Diagram, PDM, dan GUI [7]. Noerlina merancang sebuah Sistem Informasi Penagihan Pasien Rumah Sakit. Rancangan dibuat dalam bentuk Use Case Diagram, PDM, dan GUI [8].

\section{Metodologi Penelitian}

Penelitian dilakukan dengan menggunakan Metode TAS. Metode TAS pernah diterapkan oleh oleh Rika dan Michael Yoseph Ricky dalam jurnal yang berjudul "Analisis dan Perancangan Sistem Informasi Laboratorium Rumah Sakit Kanker Dharmais dengan menggunakan Total Architecture Syntesis" [4]. Total Architecture Synthesis merupakan metode yang dilakukan dengan beberapa tahap perancangan. Tahap-tahap tersebut antara lain: [6]

a. Menentukan Initial Scope.

b. Menentukan Kebutuhan.

c. Mendisain Arsitektur Bisnis Proses.

d. Mendisain Arsitektur Sistem.

e. Evaluasi Arsitektur.

Prinsip dasar dari Total Architecture Syntesis jika diterapkan pada perancangan Sistem Informasi Manajemen Rumah Sakit Modul Akuntansi dan Keuangan dimulai dari penentuan intial scope atau batasan permasalahan yang ingin dibuat. Proses ini juga akan ditentukan dengan pasti apa yang ingin dibuat dan sampai mana batasan permasalahan yang ingin dikerjakan. Perancangan metode TAS adalah menentukan kebutuhan. Metode yang digunakan dalam melakukan perancangan harus direncanakan sejak awal. Suatu kebutuhan dalam suatu perusahaan harus didefinisikan secara terperinci, dalam artian kebutuhan yang sangat kecil sekalipun harus dipersiapkan. Proses dilanjutkan dengan mendisain arsitektur bisnis proses. Proses selanjutnya adalah mendisain sistem. Disain sistem dapat digambarkan menggunakan 
DFD, Diagram Berjenjang, dan rancangan Database jika diperlukan. Evaluasi rancangan merupakan tahap terakhir pada metode ini.

\section{Kajian Pustaka}

Kajian pustaka berisikan dasar teori yang menunjang dalam Perancangan Sistem Informasi Manajemen Rumah Sakit Modul Akuntansi dan Keuangan. Dalam mewujudkan tujuan pelayanan kesehatan tersebut, rumah sakit merupakan salah satu sarana yang dapat menunjang pembangunan kesehatan. Rumah sakit memiliki peran yang sangat strategis dalam upaya mempercepat peningkatan derajat kesehatan masyarakat. Pelayanan jasa kesehatan yang disediakan rumah sakit antara lain dalam bentuk pemeriksaan, perawatan, pengobatan, tindakan medis maupun tindakan diagnostik lainnya yang dibutuhkan oleh pasien. Dalam format manajemen lama (administrasi), bukan hanya lembaga layanan kesehatan seperti rumah sakit saja yang dinilai gagal oleh masyarakat, tapi hampir pada semua organisasi publik lainnya juga menunjukan kinerja yang cenderung buruk. Gelombang reformasi keuangan daerah berhubungan dengan banyak dimensi baik sistem pembiayaan, penganggaran, dan manajemen keuangan. Metode penganggaran yang digunakan adalah metode tradisional atau item line budget [2].

\subsection{Perangkat Pemodelan Sistem}

Perancangan Sistem Informasi Manajemen Rumah Sakit Modul Akuntansi dan Keuangan dibuat dengan menggunakan beberapa perangkat pemodelan sistem. DFD disebut juga dengan Diagram Arus Data (DAD). DFD adalah suatu model logika data atau proses yang dibuat untuk menggambarkan dari mana asal data, dan kemana tujuan data yang keluar dari sistem, dimana data disimpan, proses apa yang menghasilkan data tersebut, dan interaksi antara data yang tersimpan [9]. Diagram konteks adalah diagram yang digambarkan secara global atau umum dari sebuah sistem informasi yang menggambarkan aliran-aliran data ke dalam dan ke luar dari entitas luar [10]. Gambaran keseluruhan proses DFD dari Level 0 sampai Level selanjutnya dapat digambarkan menggunakan Hierarchy Chart. Hierarchy Chart atau Diagram Berjenjang merupakan diagram yang digunakan untuk menggambarkan untuk proses-proses yang ada dalam DFD [11]. Rancangan database digambarkan berupa rancangan PDM. PDM merupakan model yang menggunakan sejumlah tabel untuk menggambarkan data yang disimpan serta hubungan antar data tersebut [12].

\section{Hasil dan Pembahasan}

Hasil dan pembahasan berisi perancangan dan pembahasan dari Rancangan Sistem Informasi Manajemen Rumah Sakit Modul Akuntansi dan Keuangan

\subsection{Gambaran Umum Sistem Rumah Sakit}

Gambar 1 menunjukkan Gambaran Umum Sistem Informasi Rumah Sakit. Gambaran mencangkup hubungan antar modul pada sistem. 


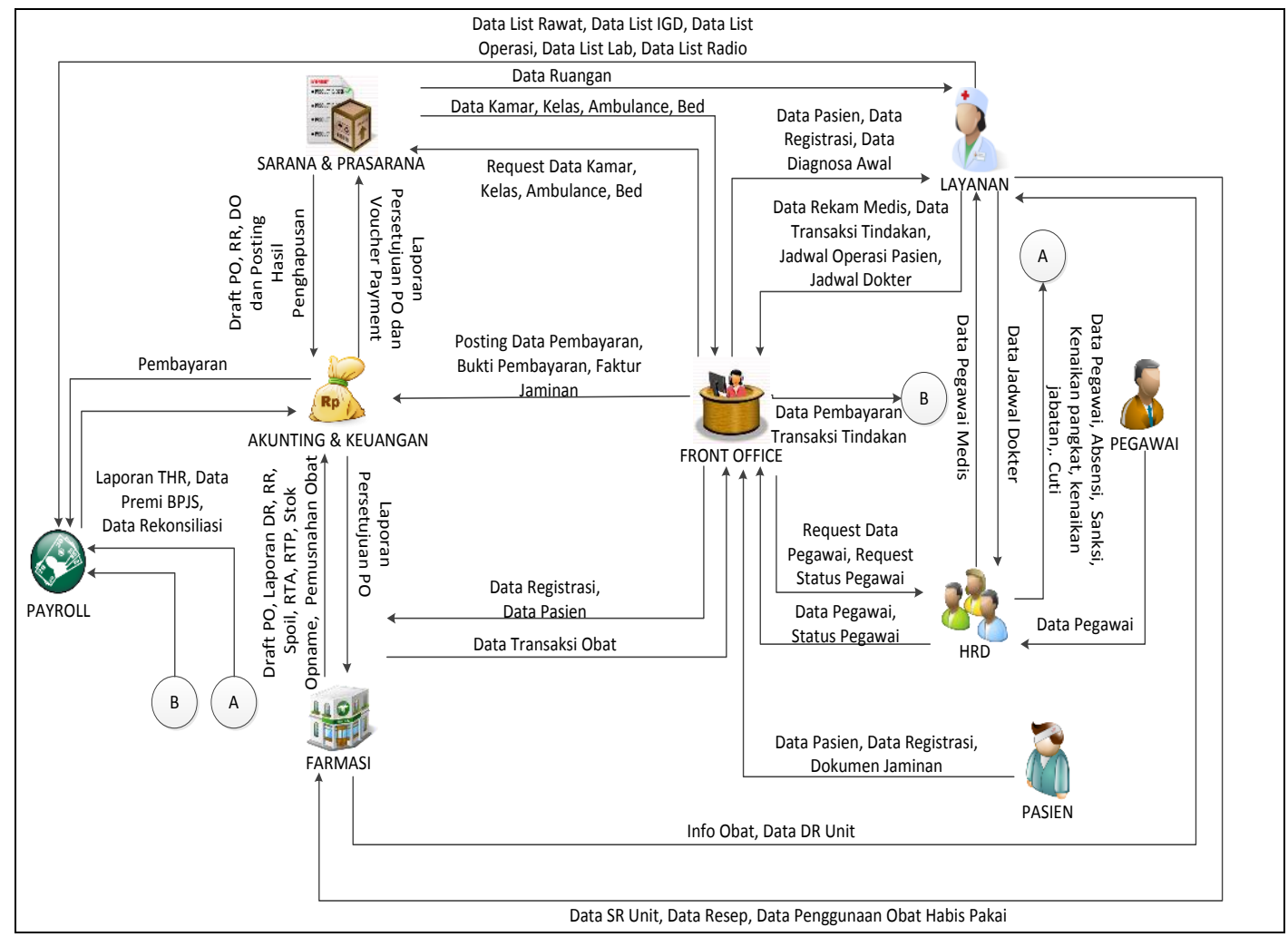

Gambar 1. Gambaran Umum Sistem

Gambar 1 menunjukkan Sistem Informasi Akuntansi dan Keuangan yang dirancang berkaitan dengan lima modul lainnya. Enam modul tersebut adalah Front Office, Layanan, Farmasi, Sarana \& Prasarana, Human Resource Development, dan Payroll. Pertukaran data diperlukan karena tiap proses dalam sebuah sistem, memerlukan data dari modul lain untuk dapat menjalankan proses tersebut.

\subsection{Konteks Diagram Sistem}

Diagram Konteks Subsistem Akuntansi dan Keuangan rumah sakit memiliki 15 entitas luar. Hubungan antara Subsistem Akuntansi dan Keuangan dengan entitas luar seperti pada Gambar 2. Gambar 2 menunjukan gambaran umum Sistem Akuntansi dan Keuangan. Hubungan sistem Akuntansi dan Keuangan dengan entitas tersebut dapat dijabarkan sebagai berikut:

\section{a. Akunting}

Entitas dari bagian Akuntansi dan Keuangan ialah pegawai pada Bagian Keuangan yang bertugas mengelola manajemen data pada Modul Akuntansi dan Keuangan.

b. Kepala Akuntansi dan Keuangan

Entitas Kepala Akuntansi dan Keuangan adalah Manajer atau atasan dalam Subsistem Akuntansi dan Keuangan, dapat menyetujui anggaran dan menerima laporan keuangan.

c. Direktur Utama

Entitas Direktur RS adalah penanggungjawab tertinggi operasional dan administrasi pada rumah sakit.

d. Supplier

Supplier adalah Merupakan Entitas Supplier Barang yang memenuhi kebutuhan peralatan medis maupun non-medis dalam rumah sakit.

e. Bank

Entitas Bank adalah sebagai pihak ketiga dalam pembayaran pajak ke Kantor Pajak. 
f. Kantor Pajak

Entitas Kantor Pajak adalah Bapak Perpajakan Negara yang mengurus pajak baik pajak pph 21, pph22, dan pph 23.

g. Finance

Entitas Finance adalah salah satu bagian dari AP dalam proses transaksi pembayaran.

h. General Cashier

Entitas General Cashier adalah pihak yang mengatur arus kas baik dalam segi pengeluaran maupun pemasukan keuangan dalam bisnis proses rumah sakit.

i. Jaminan Kesehatan

Entitas Jaminan Kesehatan adalah Perusahan Jaminan yang bekerja sama dengan rumah sakit.

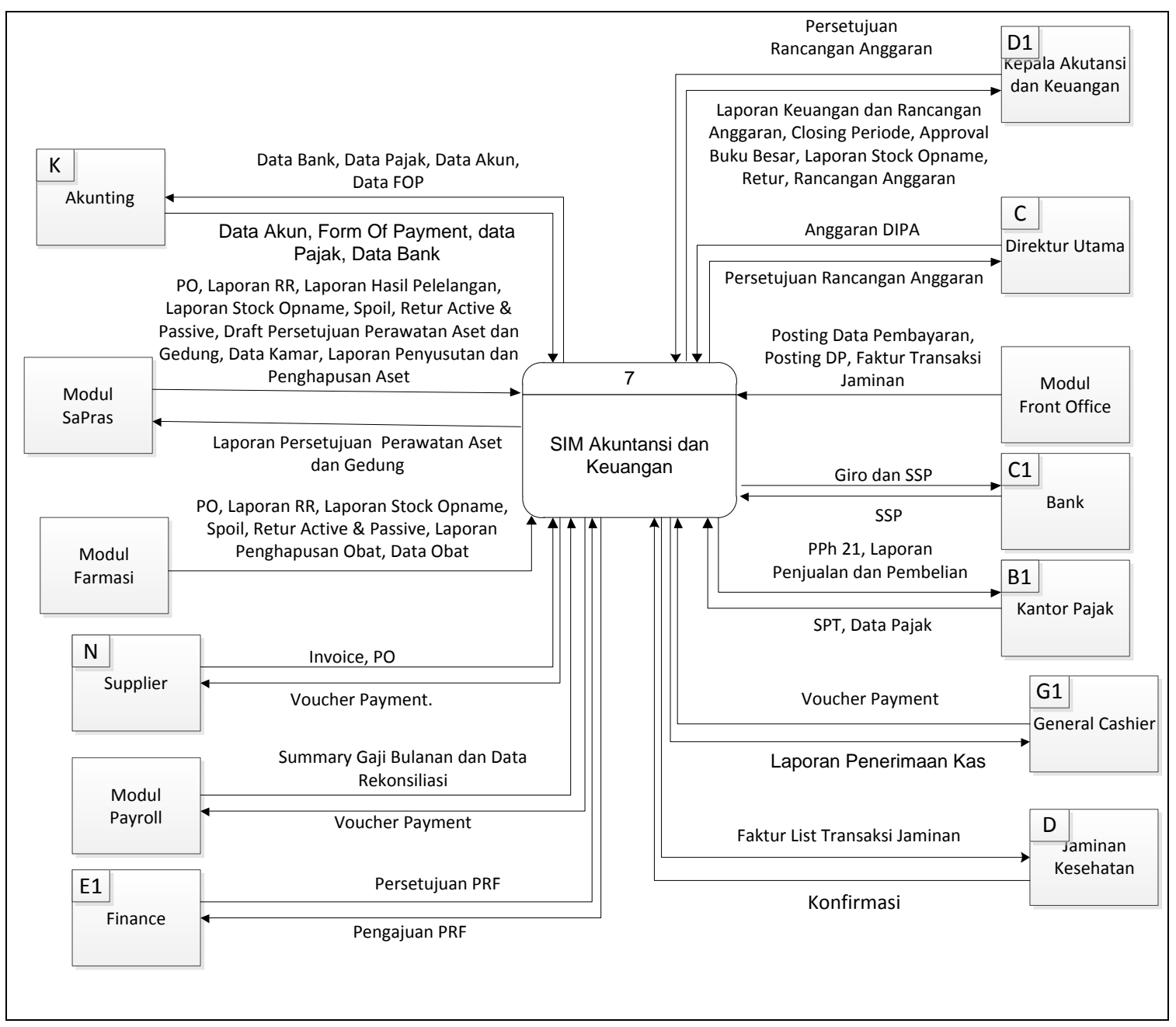

Gambar 2. Diagram Konteks Sistem

\subsection{Hierarchy Chart}

Gambar 3 merupakan gambar Diagram Berjenjang atau Hierarchy Chart dari Sistem Informasi Rumah Sakit Modul Akuntansi dan Keuangan. Diagram Berjenjang atau Hierarchy Chart digunakan untuk menggambarkan proses-proses dari Overview Diagram hingga Diagram Alir Data Level selanjutnya.

Gambar 4 menunjukan Overview Diagram Modul Akuntansi dan Keuangan. Alur Modul Akuntansi terdiri dari proses manajemen master data akun,fix asset, account payable, account receivable, buku besar, dan laporan keuangan. Pada proses manajemen data akun yakni 
penyetelan nomor rekening kesetiap transaksi-transaksi yang terjadi setiap modul dalam rumah sakit. Nomor rekening diberikan ke setiap modul maka laporan Modul Akuntansi dan Keuangan akan menarik dari setiap transaksi permodulnya untuk dijadikan jurnal.

Proses Account Payable adalah proses transaksi pembelian baik dalam Modul Farmasi, Modul Sarana Prasarana dimana mereka akan menyerahkan PO yang akan di beli kepada pihak ketiga yakni supplier, baik supplier obat maupun barang ATK. Pada proses ini juga mencatat transaksi pembayaran ke Kantor Pajak, dimana melalui pihak ketiga yakni Bank. Semua transaksi pembayaran yang terjadi dalam proses AP ini akan di tulis dalam jurnal transaksi pengeluaran.

Proses Account Receivable adalah proses dimana menerima laporan-laporan pembayaran, salah satu contohnya yakni posting laporan dari Modul Front Office, dengan kata lain proses AR ini adalah proses penerimaan kas, segala transaksi penerimaan ini akan di tulis dalam jurnal penerimaan kas.

Proses Buku Besar adalah proses pembukuan dilakukan dalam sistem berskala baik 3 bulan maupun 1 tahun sekali tergantung kebijakan perusahaan, pada tahap awal buku besar berfungsi sebagai mengatur saldo awal periode dimana saldo tersebut akan digunakan dalam periode selanjutnya, setelah itu proses buku besar akan merekap jurnal-jurnal baik dalam proses AP maupun AR akan dibuatkan laporan keuangan. Semua proses tersebut akan masuk kedalam account summary yakni rekapan akun yang digunakan sebagai penyimpanan data rekapan.

Proses Pelaporan adalah proses pada Modul Akuntansi dan Keuangan yang dapat membantu pembuatan laporan untuk diberikan ke Direktur Utama. Pelaporan pada Modul Akuntansi terdiri dari tiga yakni, neraca keuangan, neraca saldo, dan laba rugi.

Hierarchy chart pada Gambar 3 menunjukkan proses-proses Diagram Alir Data Rancangan Sistem Modul Akuntansi dan Keuangan dibuat sampai Level dua. Diagram Alir Data Level 1 merupakan subproses dari proses-proses utama pada Overview Diagram. Diagram Alir Data Level 2 merupakan subproses dari Diagram Alir Data Level 1.

\subsection{Overview Diagram}

Diagram Level 0 atau Overview Subsistem Akuntansi dan Keuangan terdiri dari 6 proses yang melibatkan 20 datastore internal. Diagram Level 0 atau Overview Subsistem Akuntansi dan Keuangan dapat dilihat pada Gambar 4. 
LONTAR KOMPUTER VOL. 6, NO.3, DESEMBER 2015 DOI: 10.24843/LKJITI.2015.v06.i03.p01

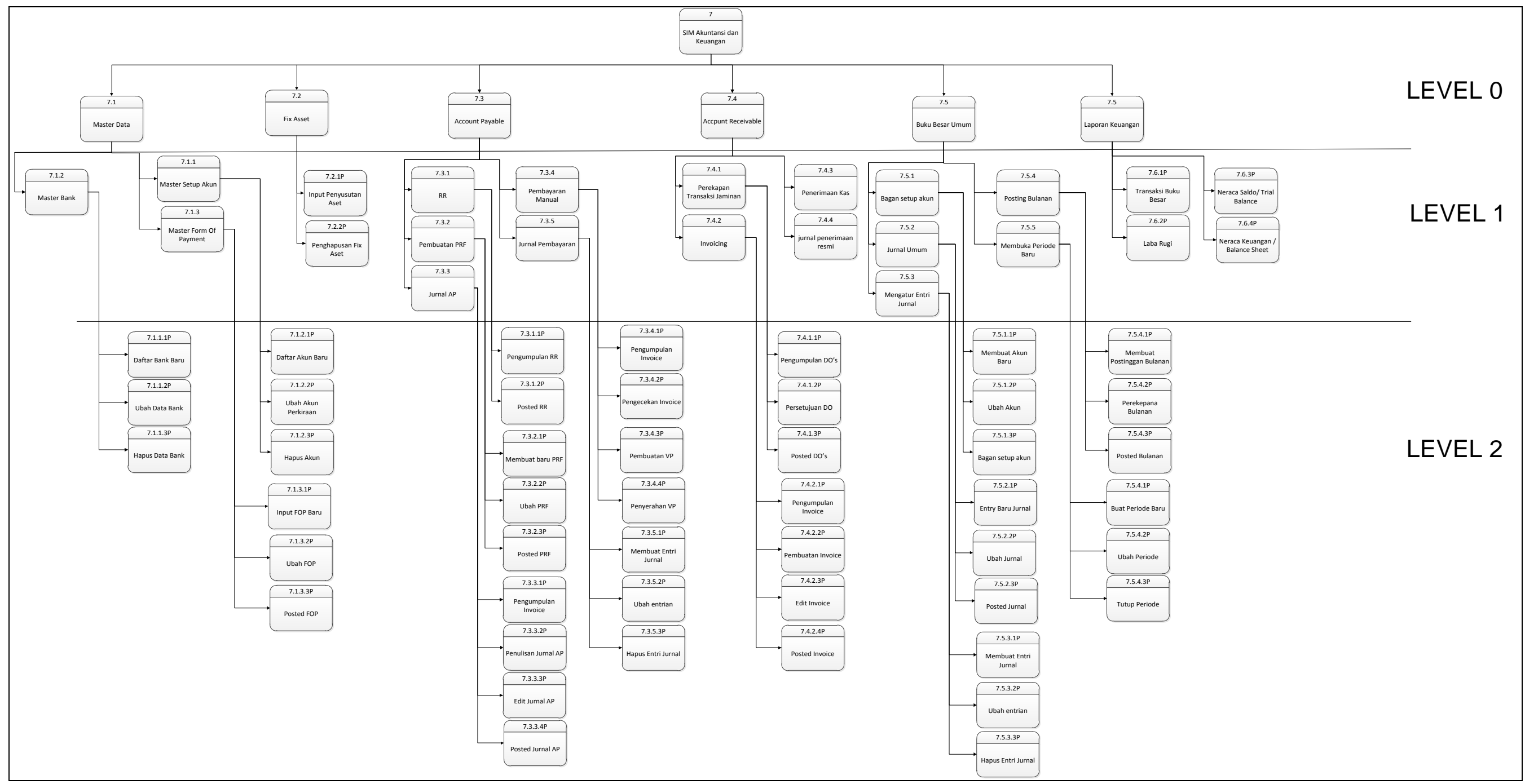

Gambar 3. Hierarchy Chart 


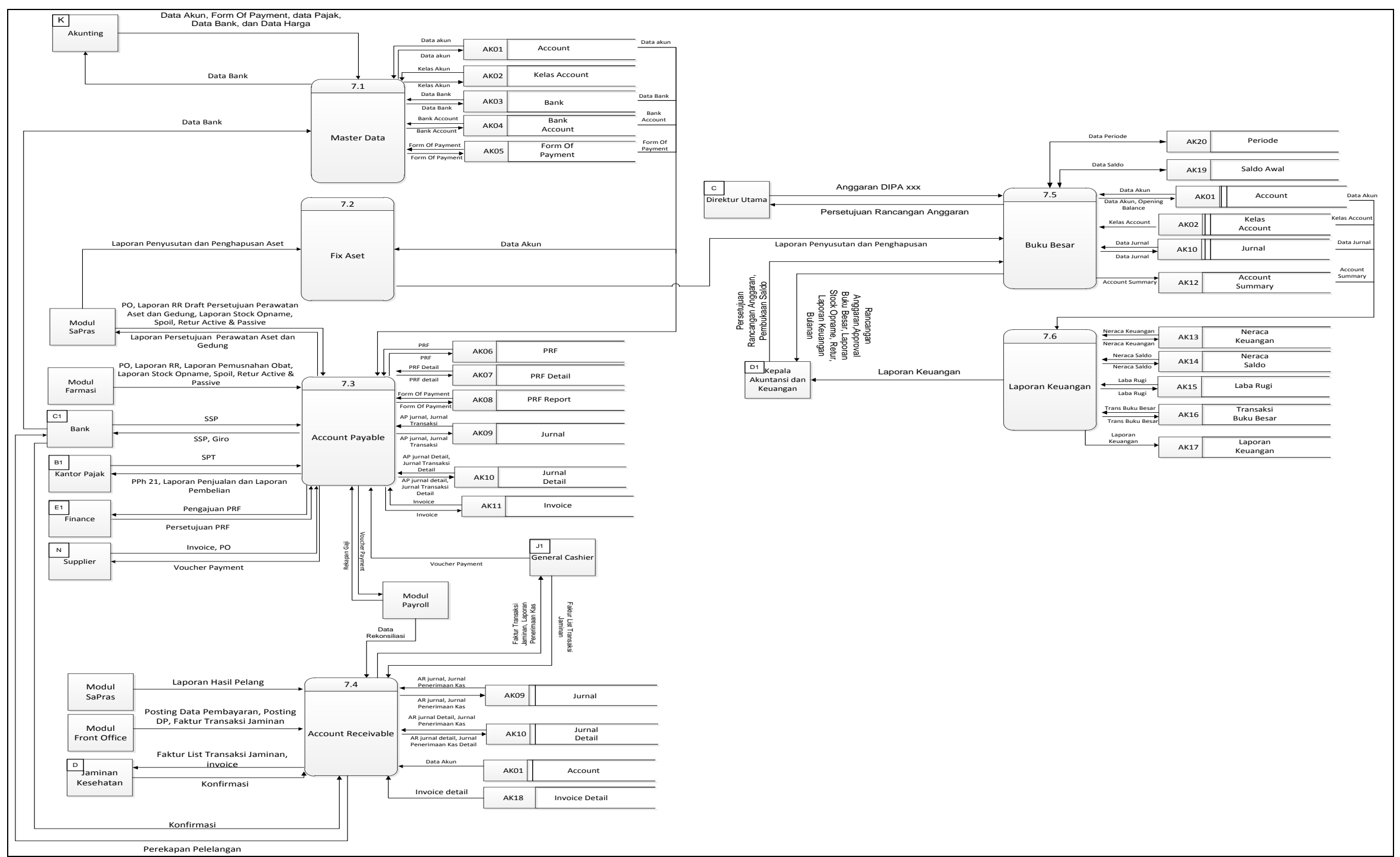




\subsection{Diagram Alir Data Level 1 Account Payable}

Diagram Alir Data Level 1 AP menunjukan subproses dari Proses AP pada Overview Diagram. DFD Level 1 AP terdiri dari lima subproses utama di dalamnya. lima subproses yang terdapat pada DFD Level 1 AP antara lain pengumpulan RR, pembuatan PRF, pencatatan di Jurnal AP ,pembayaran atau persetujuan PRF, dan jurnal pembayaran lima proses pada Gambar 5 Menunjukan keteraitan antar tiap subproses dengan entitas-entitas yang berhubungan dengan Proses AP pada Overview Diagram.

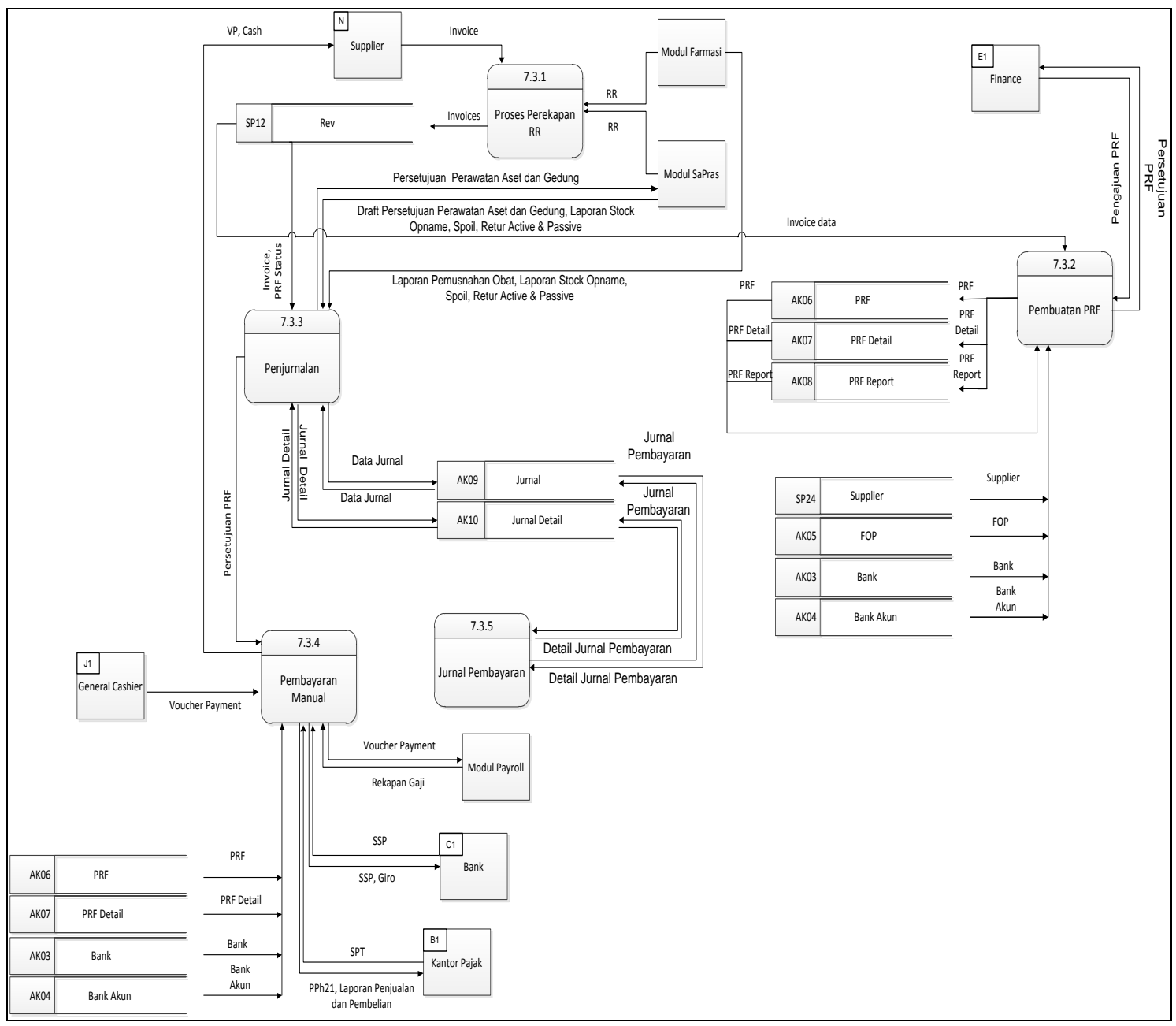

Gambar 5. Diagram Alir Data Level 1 Account Payable

Pada Gambar 5 menjelaskan proses AP (Account Payable) terdapat 5 subproses yakni pengumpulan RR dari bagian Sarana Prasarana dan Farmasi merupakan laporan untuk barang yang sudah datang, dan diberikannya laporan tersebut bersamaan dengan invoice yang dikirim dengan supplier, proses selanjutnya adalah pembuatan PRF (Payment Requitition Form), pembuatan PRF berdasarkan pengumpulan RR lalu ke proses pencatatan di Jurnal AP sebagai bukti transaksi, dan proses selanjutnya adalah pembayaran atau persetujuan PRF tersebut ke dalam VP (Voucher Payment) dan proses akhir adalah pencatatan dalam jurnal pembayaran.

Lima proses pada gambar 5 menunjukan keterkaitan antar tiap subproses dengan entitasentitas yang berhubungan dengan proses AP pada Overview Diagram. 


\subsection{Perancangan Database}

Rancangan Database dibuat dalam bentuk PDM. PDM menunjukan tempat penyimpanan data selama sistem berjalan.

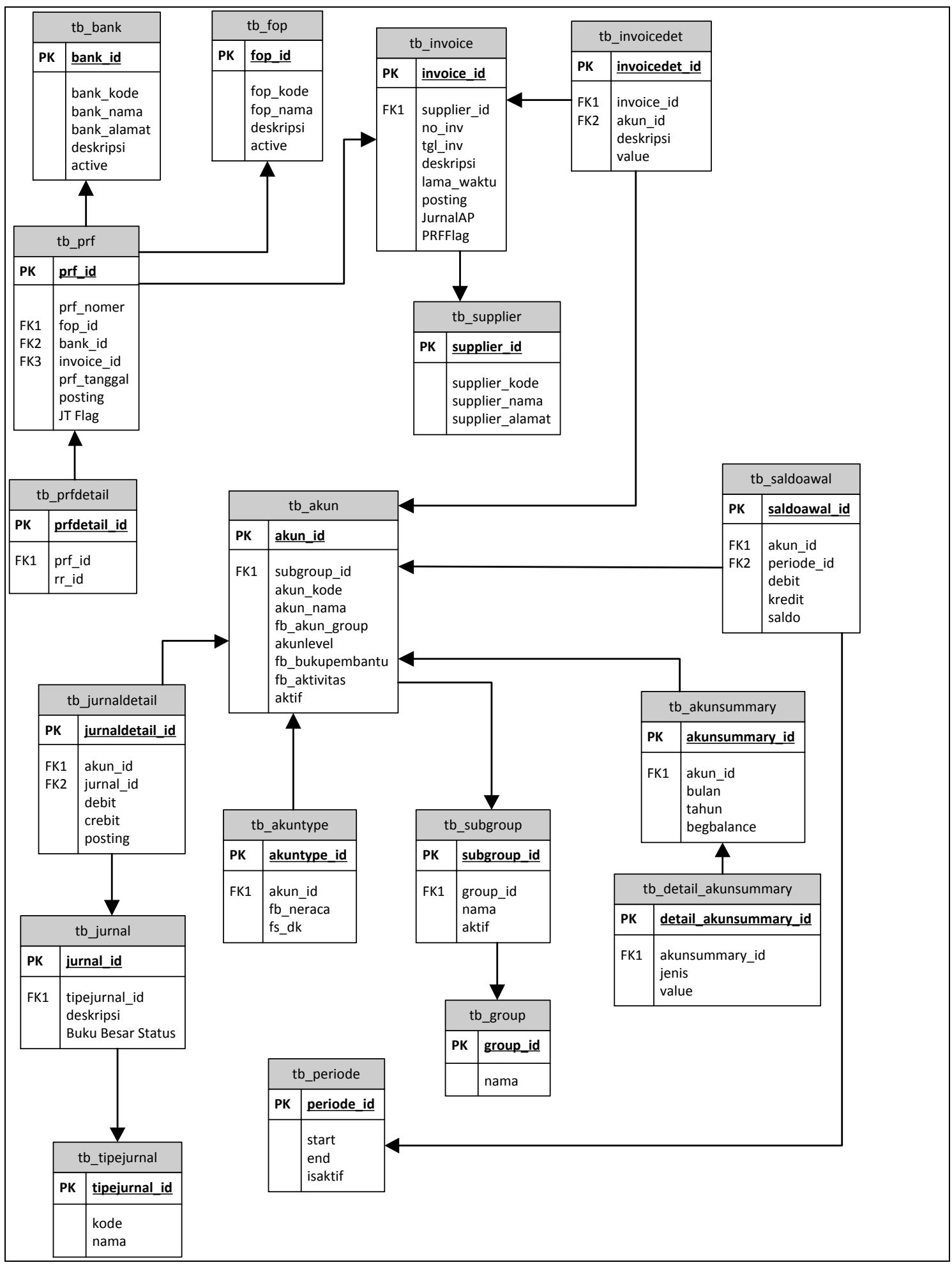

Gambar 6. Database SIMRS Modul Akuntansi 
Gambar 6 menunjukkan rancangan PDM tempat penyimpanan data dari enam proses utama Sistem Rumah Sakit Modul Akuntansi yaitu Manajemen Master Data Akun, Kelas akun, FOP, dan Bank.

\subsection{Perancangan Graphical User Interface}

Desain GUI (Graphical User Interface) dibuat untuk menentukan tampilan rancangan Sistem Informasi Manajemen Rumah Sakit, khususnya untuk Modul Akuntansi dan Keuangan. Tampilan form login Sistem Informasi Manajemen Rumah Sakit Universitas Udayana adalah sebagai berikut.

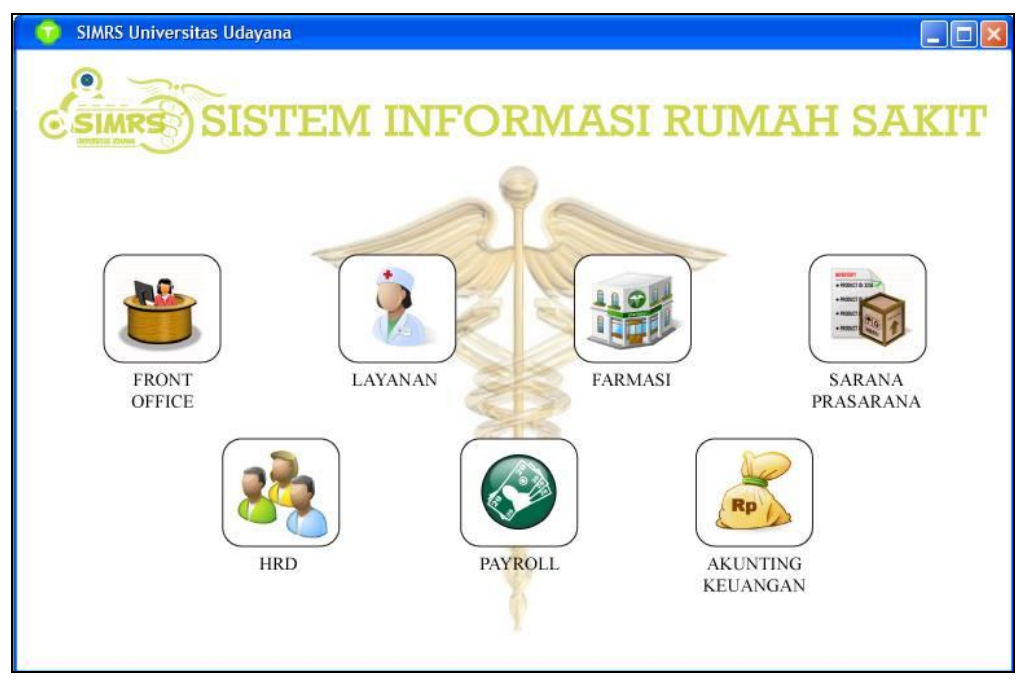

Gambar 7. Form Home

Tampilan Home setelah login merupakan tampilan bagi administrator umum sehingga dapat terlihat pilihan semua modul yang ada seperti berikut.

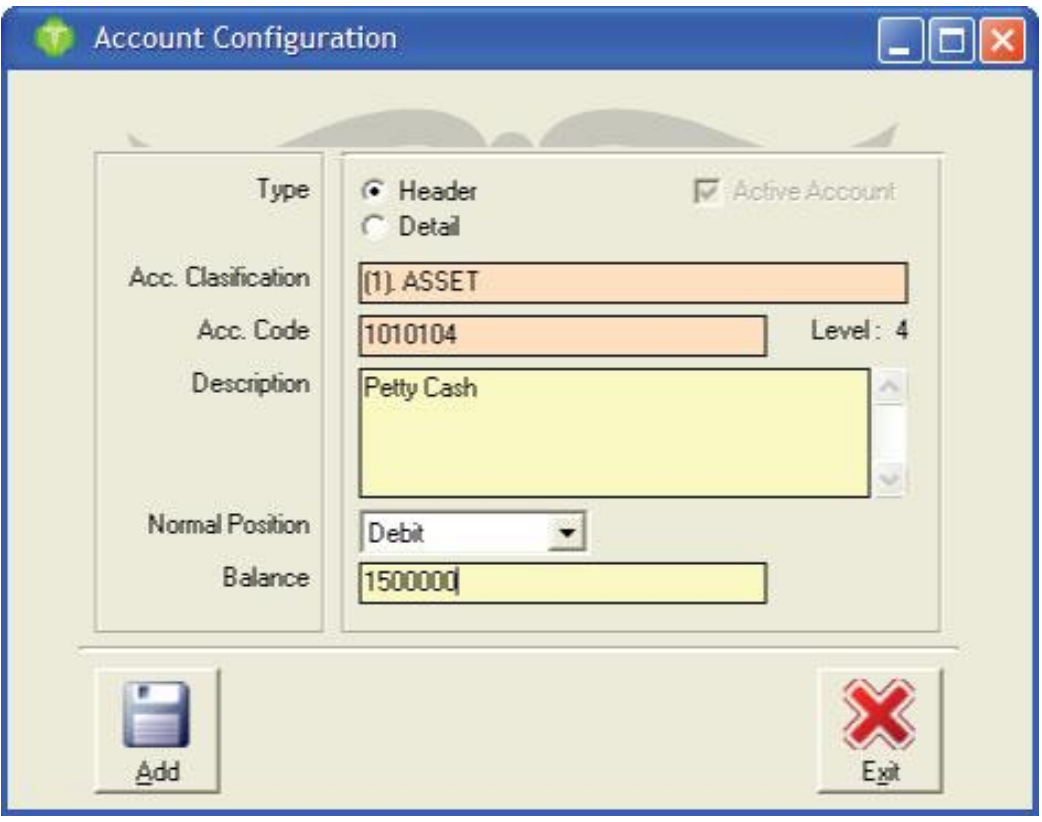

Gambar 8. Setup Account

Dalam Pembuatan Modul Akuntansi dan Keuangan diperlukannya sebuah Account, pada Gambar 8 menjelaskan mengenai Setup Account dalam akun ASSET. 


\section{Kesimpulan}

Perancangan sistem informasi dibuat dengan harapan dapat dikembangkan dan mengganti proses manual di rumah sakit, sehingga kelemahan-kelemahan yang terjadi jika menggunakan proses manual dapat diatasi. Perancangan Sistem Informasi Manajemen Rumah Sakit yang dibuat merupakan sistem informasi yang terintegrasi dengan modul lain, dan terbukti dengan adanya pertukaran data antar modul. Perancangan Modul Akuntansi memiliki lima proses utama didalamnya antara lain Manajemen Master Data, Account Payable, Account Receivable, Buku Besar,dan Pelaporan. Rancangan dibuat dalam bentuk Diagram Relasi Antar Modul, Diagram Alir Data, Diagram Konteks, Diagram Berjenjang, Overview Diagram, Database, dan Graphical User Interface.

\section{Daftar Pustaka}

[1] Departemen Kesehatan Republik Indonesia, Ketentuan Umum Indonesia. 2009.

[2] F. Armen and V. Azwar, Dasar-Dasar Manajemen Keuangan Rumah Sakit. 2013.

[3] Y. A. Nugraha Paturusi, I. M. Sukarsa, and I. G. Made Arya, "Hospital Information Sharing based on Social Network Web," International Journal of Computer Application, 2012.

[4] Rika and M. Y. Ricky, Analisis dan Perancangan Sistem Informasi Laboratorium Rumah Sakit Kanker Dharmais dengan Menggunakan Metode Total Architecture Synthesis. 2008.

[5] R. Nur, N. Beta, and N. Bahtiar, "Pembangunan Website Informasi Pelayanan Rumah Sakit Cakra Husada Klaten," Journal of Informatics and Technology, vol. 1, no. 1, pp. 110, 2012.

[6] I. Dwi Jaya, "Sistem Informasi Rumah Sakit Dr. Ak. Gani Palembang," Teknomatika, vol. 1, no. 3, pp. 323-346, 2011.

[7] R. Mukti, Eky Bangun \& Miguani \& effendi, "PERANCANGAN SISTEM INFORMASI RAWAT JALAN BERBASIS DESKTOP ( Studi Kasus pada Puskesmas Brati Kab . Grobogan )," Jurnal Teknologi Informasi dan Komunikasi, 2013.

[8] Noerlina, "Rancangan Sistem Informasi Penagihan Pasien Rumah Sakit," in Seminar Nasional Informatika, 2010, pp. 132-138.

[9] R. Afyenni, "Perancangan Data Flow Diagram untuk Sistem Informasi Sekolah (Studi Kasus Pada SMA Pembangunan Laboratorium UNP)," Jurnal Teknoif, 2014.

[10] W. Nur Laila, "Sistem Informasi Pengolahan Data Inventory pada Toko Buku Studi CV. Aneka Ilmu Semarang," Jurnal Teknik Elektro, vol. 3, no. 1, p. 38, 2011.

[11] Y. Yuliawan, M. J. D. Sunarto, and T. Soebijono, "Pengembangan Sistem Informasi Pendataan Jemaat Gereja Masehi Advent Hari Ketujuh Konferensi Jawa Kawasan Timur Berbasis Web," Jurnal JSIKA, vol. 2, no. 2, p. 86, 2013.

[12] A. Farabi and Machfud, "Analisis dan Desain Sistem Penunjang Keputusan Penebangan Tebu (Studi Kasus di PT. Rajawali II Unit PG. Jatitujuh, Majalengka)," E-Jurnal Agroindustri Indonesia, vol. 1, no. 1, p. 51, 2012. 